\title{
A Rare Case of Synchronous Pleomorphic Adenoma and Lobular Capillary Hemangioma of Nasal Septum
}

\author{
Yun Ji Lee ${ }^{1}$ D , Shin Young Kim ${ }^{1}$, Jiyoon $\mathrm{Kim}^{2}$, and Ji Ho Choi ${ }^{1} \mathbb{D}$ \\ ${ }^{1}$ Departments of Otorhinolaryngology-Head and Neck Surgery, ${ }^{2}$ Pathology, Bucheon Hospital, Soonchunhyang University \\ College of Medicine, Bucheon, Korea
}

\author{
비중격에 동시에 발생한 다형성 선종 및 소엽성 모세혈관종 1 예 \\ 이윤지 ${ }^{1} \cdot$ 김신영 $^{1} \cdot$ 김지윤 $^{2} \cdot$ 최지호 $^{1}$ \\ 순천향대학교 의과대학 부천병원 이비인후-두경부외과학교실, ${ }^{1}$ 병리학교실 ${ }^{2}$
}

\author{
Received May 19, 2020 \\ Revised August 24, 2020 \\ Accepted September 14, 2020 \\ Address for correspondence \\ Ji Ho Choi, MD, PhD \\ Department of Otorhinolaryngology- \\ Head and Neck Surgery, \\ Bucheon Hospital, \\ Soonchunhyang University \\ College of Medicine, \\ 170 Jomaru-ro, Bucheon 14584 \\ Korea \\ Tel $+82-32-621-5015$ \\ Fax $+82-32-621-5016$ \\ E-mail handsomemd@hanmail.net
}

\begin{abstract}
Pleomorphic adenoma is the most common benign tumor of major salivary gland, but it rarely originates from the nasal cavities. Meanwhile, the lobular capillary hemangioma, known as pyogenic granuloma, is also a benign tumor of unclear etiology unusually found in the sinonasal area. Little is known about cases where pleomorphic adenoma and lobular capillary hemangioma originate simultaneously in the nasal cavity. Here, we report a case of 63 -year-old female with pleomorphic adenoma and lobular capillary hemangioma simultaneously arising from the nasal septum. After endoscopic tumor resection, there was no recurrence or complication during the follow-up.

Korean J Otorhinolaryngol-Head Neck Surg 2021;64(9):664-8
\end{abstract}

Keywords Lobular capillary hemangioma; Nasal septum; Pleomorphic adenoma.

\section{서 론}

다형성 선종(pleomorphic adenoma)은 타액선에서 발생하 는 가장 흔한 양성 종양이나 비강 및 부비동 내에서의 발생 률은 매우 낮은 질환이다.1) 비부비동 내에서 발생한 경우 반 수 이상이 비중격에서 기원하는 것으로 알려져 있다.") 이 질 환은 약 $6 \%$ 에서 악성 변화 가능성이 있어 감별 진단 및 추적 관찰 시 주의해야 한다. ${ }^{2)}$ 과거 화농성 육아종(pyogenic granuloma)으로 알려져 있는 소엽성 모세혈관종(lobular capillary hemangioma) 또한 피부나 구강 점막, 특히 입술 등에 흔히 발생하는 양성 질환이다. ${ }^{3)}$ 정확한 발생 원인은 아직 알 려져 있지 않으며, 두경부에 발생하는 경우 7 29\%에서 비강

This is an Open Access article distributed under the terms of the Creative Commons Attribution Non-Commercial License (https://creativecommons.org/licenses/by-nc/4.0) which permits unrestricted non-commercial use, distribution, and reproduction in any medium, provided the original work is properly cited.
내 특히 전방부 비중격에서 가장 흔히 발생하는 것으로 보고 되고 있다. ${ }^{3)}$ 아직까지 다형성 선종과 소엽성 모세혈관종이 함께 동시에 비강에서 관찰된 경우는 거의 알려진 바 없었다. 따라서, 저자들은 편측 비중격 점막에서 상기 두 질환이 동 시에 발생한 환자의 진단 및 치료를 경험하였기에 이를 본 증 례에서 관련 문헌과 함께 고찰하려 한다.

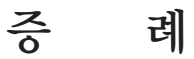

고혈압 과거력이 있는 63세 여성이 내원 3주 전부터 발생 한 반복적인 좌측 비출혈을 주소로 본원 이비인후과 내원하 였다. 출혈량은 많지 않았으나 매일 지속적으로 1 2회씩 비 출혈이 반복되었고 지혈은 비교적 잘 되었다고 하였다. 환자 는 아스피린 등 항혈소판 제재는 복용하지 않았고 비폐색이 나 비루, 후각 저하 등 다른 비증상은 호소하지 않았다. 외상 
이나 수술을 시행한 과거력은 없었다. 외래에서 시행한 비내 시경 검사 결과 좌측 비강 내에 비중격 전방의 점막에서 기인 하여 비강 내로 돌출한 양상의 표면이 매끄러운 종물이 관찰 되었다. 또한 이 종물에 인접하여 매끄러운 표면의 보라빛 아 령 형태의 종물이 확인되었으며 이는 일부 가피로 덮혀 있었 으나 출혈 소견은 보이지 않았다(Fig. 1).

병변의 범위 및 성상을 파악하기 위해 부비동 전산화단층 촬영 검사를 시행하였다. 좌측 비강 내에 비중격에서 기인한 양상의 약 $0.3 \mathrm{~cm}$ 의 종물이 확인되었다. 또한 이 병변에 인 접하여 $0.8 \times 0.6 \mathrm{~cm}$ 크기의 강하게 조영 증강되는 아령 모양
병변이 확인되었으며, 이는 혈관종(hemangioma)을 의심할 수 있는 소견이었다(Fig. 2). 종물은 비강 내에 국한되어 있었 으며 주변 골파괴 소견은 보이지 않았고 동반된 점막의 증식 이나 비부비동염의 소견은 없었다.

병변의 크기가 비교적 작고 비중격 전방에 위치하여 병변 의 전체 범위를 파악하기 용이하였으므로 전신 마취 하 내시 경적 적출을 계획하였다. 술전 부비동 전산화단층촬영 검사 상 혈관종을 의심할 수 있었으나, 수술 중 대량 출혈의 가능 성은 낮다고 판단되어 술전 색전술은 고려하지 않았다. 전방 의 비중격 점막을 돌출시키는 종물과, 이에 인접해 있는 아령
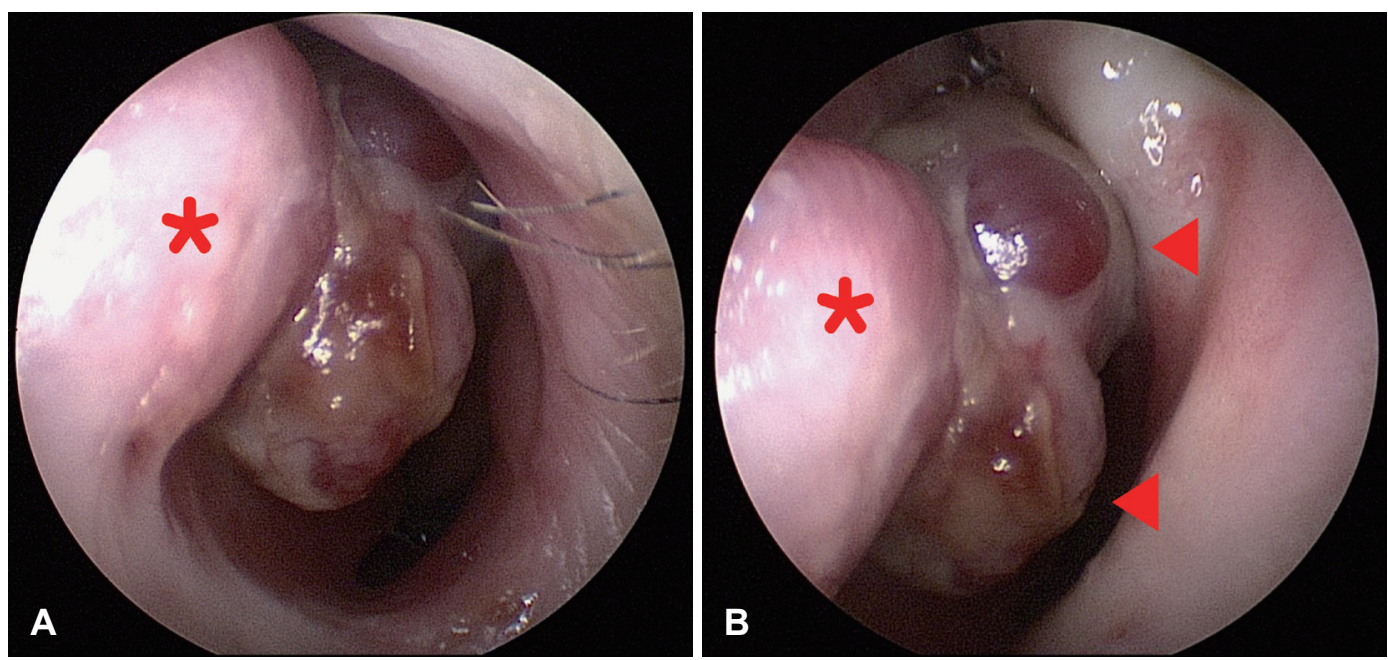

Fig. 1. Preoperative endoscopic findings. Endoscopic finding of left nasal cavity shows bulging contoured mass like lesion originating from left nasal septum, confirmed as pleomorphic adenoma (asterisk) (A). Just next to this lesion (asterisk), bilobulating mass with reddish, smooth surface is occupying the nasal cavity, revealed as lobular capillary hemangioma (arrowheads) (B).
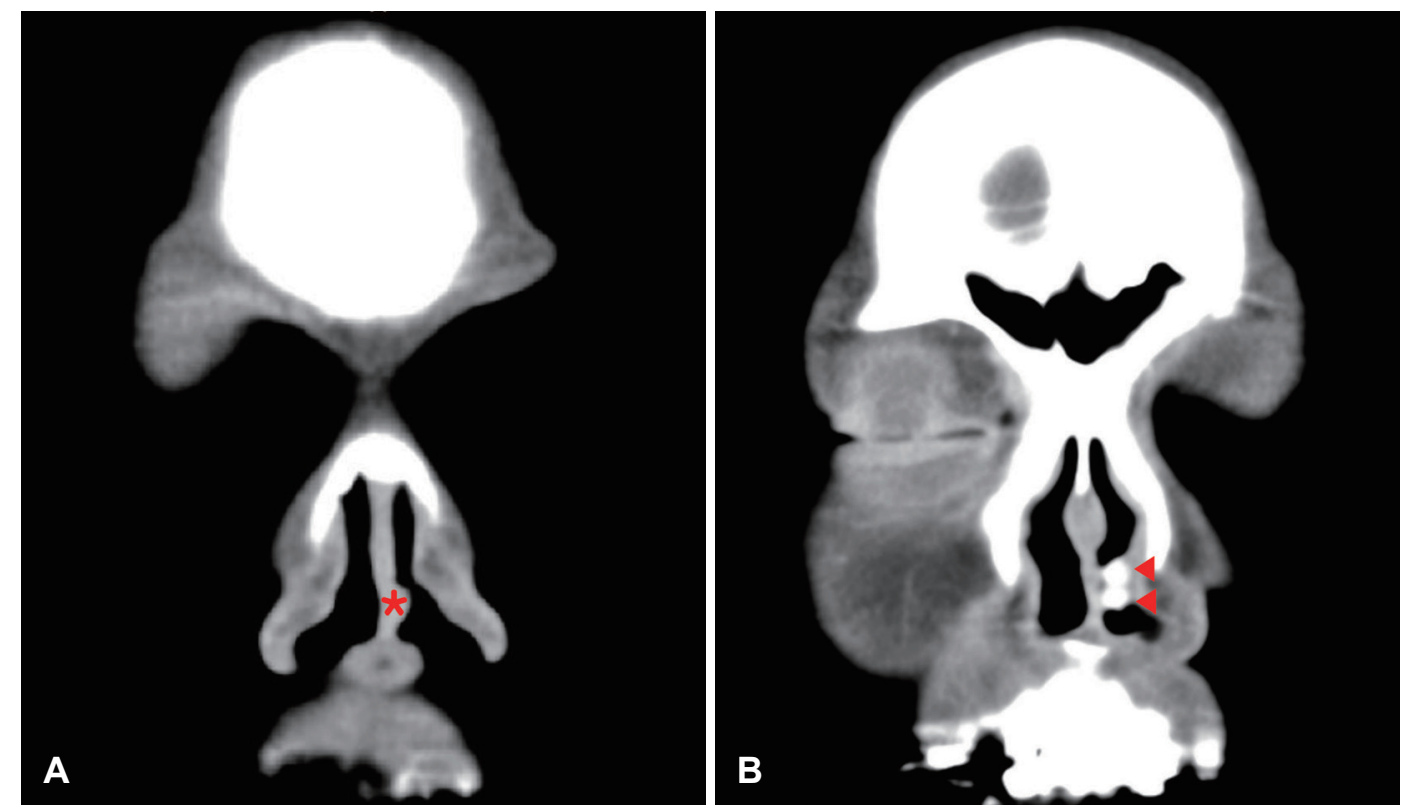

Fig. 2. Contrast enhanced axial paranasal CT images. About $0.3 \mathrm{~cm}$ sized protruding mass is originated from nasal septum (asterisk) (A). Another dumbbell shaped mass with strong homogenous enhancement is abutting to the previously mentioned mass (arrowheads) (B). This means that this tumor contains lots of vessels, suggesting hemangioma. 

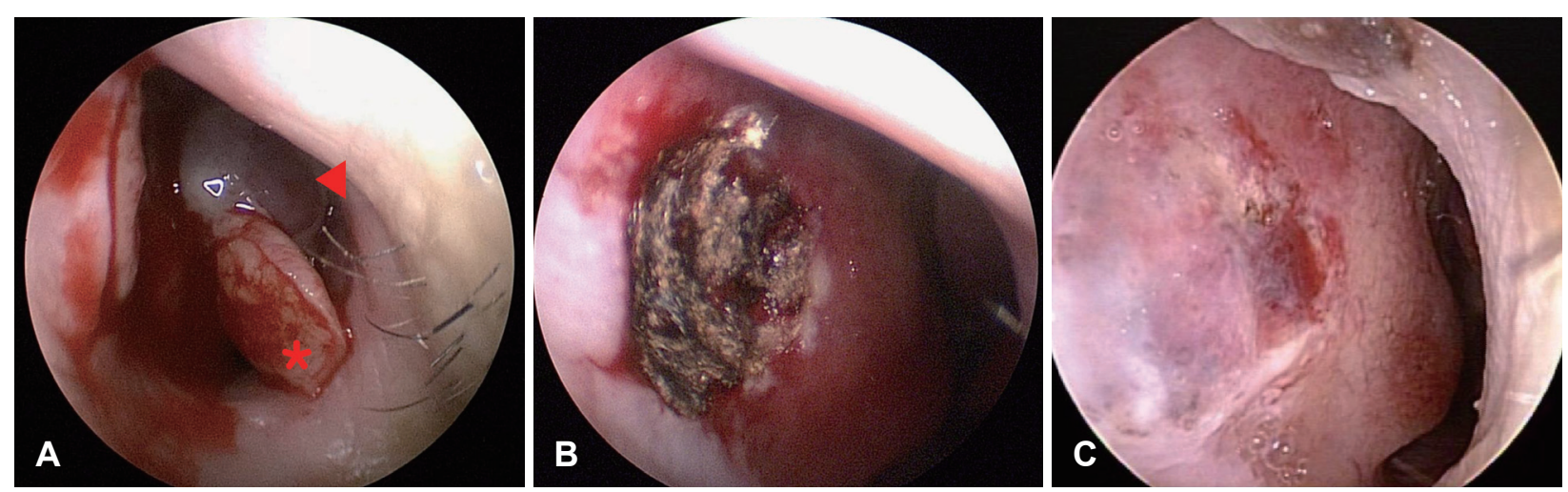

Fig. 3. Endoscopic findings during and after surgery. This shows just after dissecting the protruding lesions of the nasal septum. The anterior lesion was well-demarcated solid greyish white submucosal mass with nodularity (asterisk). The posterior one was originated from the septal mucosa adjacent to the anterior one (arrowhead) (A). The masses were totally excised including nasal septal mucosa and the operative bed was electro-cauterized (B). Two-month after surgery, there was no evidence of recurrence and the septal mucosa recovered well $(\mathrm{C})$.

모양의 병변을 일괴 절제(en bloc resection)하였다(Fig. 3). 전방에 위치한 병변은 점막 하 종물의 양상을 보이며, 회백 색을 띄고 주위 점막과 경계가 명확하게 구분되었다. 이 병변 과 인접하여 구분된 비점막에서 기인하는 양상으로 후방의 아령 모양 종물이 비강 내로 돌출되어 있었다. 충분한 정상 점막 절제연을 확보하기 위해 비중격 점막 일부를 포함하여 비중격의 종물을 모두 제거하였다. 지혈 후 비중격에 부목을 거치한 뒤 수술을 종료하였다.

조직 검사상 다형성 선종과 소엽성 모세혈관종으로 서로 다른 2 개의 구분된 종양이 확인되었다(Fig. 4). 검체의 심층 에 위치한 다형성 선종은 섬유성 캡슐로 둘러 싸여있는 경계 가 명확한 타원형 모양의 종괴였다. 이것은 상피 세포(epithelial cell)와 근상피 세포(myoepithelial cell), 그리고 특징적인 연골 점액양 기질(chondromyxoid stroma)로 구성되어 있었 다. 상피 표지자 cytokeratin 7과 근상피 표지자 p63이 각각 의 부위에서 양성으로 확인되었다. 한편, 아령 모양의 종괴는 검체의 표층에 위치하였고, 편평 상피(squamous epithelium) 로 덮혀 있었으며 표면의 일부 미란(erosion)이 확인되었다. 이 종괴에서 모세혈관들의 증식 소견 및 CD34 면역조직화학 염색(immunohistochemical stain)을 통해 혈관 내피 세포 (endothelial cells)의 증식을 확인하였고, 이것은 소엽성 모세 혈관종에 합당하였다.

술후 이틀 째에 전비공 패킹을 제거한 이후 특별한 합병증 없이 환자는 퇴원하였고, 술후 2개월째 비내시경상 수술 부위 비중격 점막은 회복되었으며 술후 1년 9개월째 국소 재발의 소견 없이 외래 추적 관찰 중이다. 본 연구는 순천향대학교 부 천병원 임상연구심의위원회의 승인을 받았다(2020-03-021).

\section{고 찰}

본 증례는 다형성 선종과 소엽성 모세혈관종이 비중격의 전방 부위에서 동시에 발생한 경우로 이러한 경우를 기존 문 헌들에서는 찾아볼 수 없을 정도로 매우 드문 증례로 생각 된다. 아울러, 비강 내 다형성 선종과 소엽성 모세혈관종이 어떤 이유나 기전으로 발생되는지에 대해 아직까지 정확하게 밝혀져 있지 않은 상태에서 다형성 선종과 소엽성 모세혈관 종이 함께 비중격에서 기원한 이유에 대해서는 명확하게 설 명하기는 어려울 것으로 사료된다.

비강 및 부비동 내의 다형성 선종은 드문 질환으로 알려져 있으며, 문헌상 증례 보고들과 소수의 체계적 문헌 고찰(systematic review)만 보고되었다.) 비강 내에서 발생하는 다형 성 선종은 비중격 부위에서 호발하는데, 그 기원에 대해서는 명확히 밝혀지지 않았으며, 여러 가설이 제시되었다. ${ }^{5)}$ 배아기 상피 세포가 일부 비중격 부위로 전위(dislocation)되어 이로 부터 유래한다는 이론과, 성숙한 침샘으로부터 유래하여 발 생한다는 이론, 비서골 기관(vomeronasal organ)의 배아기 잔여물에서 유래한다는 것 등이다. ${ }^{5)}$

최근 발표된 한 종합적 고찰(comprehensive review) 논문 에 따르면, 총 101건의 비부비동 다형성 선종 증례 중 약 $57 \%$ 가 비중격에서 기원하였으며, 약 $8 \%$ 가 최종 조직 검사 결과 다형성 선종 유래 암종(carcinoma ex pleomorphic adeno$\mathrm{ma}$ )이었다. 다형성 선종 유래 암종은 유병률이 백만 명 중 0.17 명 정도로 보고된 극히 드문 질환으로, ${ }^{2)}$ 대부분 이하선에 서 발생하며 비부비동 부위에서 발생한 것은 문헌상 소수의 증례 보고만 발표된 바 있다.5) 이 질환의 악성화 요인은 고령, 소타액선 종양인 경우로 보고되었다. ${ }^{6}$ Toluie와 Thompson ${ }^{7}$ 에 의하면, 다형성 선종 유래 암종 환자 9명에서 대부분 수 

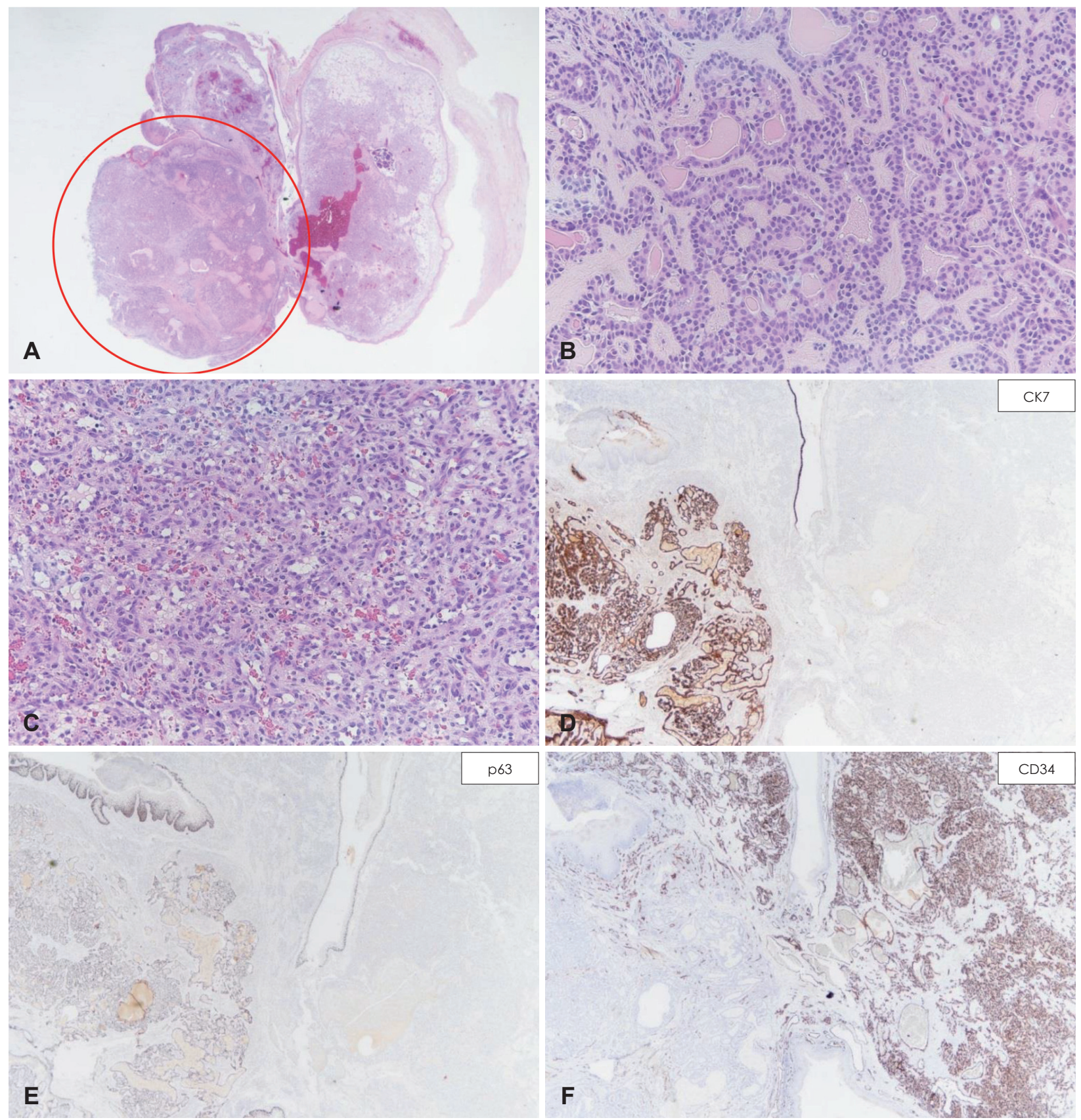

Fig. 4. The histologic features. The protruding and bilobulating masses are composed of pleomorphic adenoma (left side, red circled side) and lobular capillary hemangioma (right side, the other side). Erosion over the pyogenic granuloma component is noted (A: H\&E stain, $\times 10)$. The pleomorphic adenoma shows epithelial and myoepithelial/stromal proliferation (B: H\&E stain, $\times 200)$. The lobular proliferation of capillaries is observed in lobular capillary hemangioma component (C: H\&E stain, $\times 200)$. The epithelial and myoepithelial component of pleomorphic adenoma is immunoreactive for CK7 (D: IHC stain, $\times 40)$ and p63 (E: IHC stain, $\times 40)$, respectively, and endothelial cells in lobular capillary hemangioma show immunoreactivity for CD34 (F: IHC stain, $\times 40)$. CK7: cytokeratin 7, H\&E: hematoxylin and eosin, IHC: immunohistochemistry.

술적 치료 및 방사선 치료를 병행하여 시행하였으나 반수 이 상에서 재발하였으며, 평균 생존률은 8.4년이었다.

비부비강의 다형성 선종에 대해 수술적 완전 절제가 일차 치료법으로 사용되고 있으며, 재발 및 악성화 가능성이 있으 므로 정상 절제연을 확보하는 것이 중요하다. ${ }^{8}$ 내시경적 접근
법이 종양의 절제연을 시각화하는 데 유리하여 장점이 있으 나, 종양의 크기가 크거나 내시경적 접근이 어려운 위치에서 기원하는 경우 외측 비절제술(lateral thinotomy)이나 부분 상악절제술(partial maxilectomy) 등과 같은 외적 접근법도 사용될 수 있다.) 종양의 재발에 영향을 주는 요인으로는 종 
양의 크기가 큰 경우, 원발 부위가 부비동인 경우로 보고되었 으며, 이는 접근이 상대적으로 어렵기 때문인 것으로 사료된 다. ${ }^{1)}$ 이러한 결과는 잔여 조직을 남기지 않고 종양을 완전 절 제하는 것이 재발을 예방하는 데 중요한 요인임을 시사한다.

소엽성 모세혈관종은 비강 내에 생기는 다양한 혈관성 종 양 중 가장 흔한 형태로, ${ }^{3)}$ 화농성 육아종(pyogenic granulo$\mathrm{ma})$ 이라는 명칭으로 이전에 알려졌으나 이는 잘못된 명칭으 로서 이 질환은 염증이나 육아 조직과는 무관한 것으로 확 인되어 현재는 소엽성 모세혈관종으로 명명하고 있다.3) 흔히 임상적으로 구강 점막이나 피부에 붉은색의 쉽게 출혈하는 돔 형태의 구진으로 나타나며 비강 내에서는 특비 비중격 전 방부 또는 비갑개의 끝 부분에서 호발한다. ${ }^{3)}$ 크기가 클 경우 비인두 혈관섬유종(nasopharyngeal angiofibroma)과의 감 별이 필요하다. ${ }^{9)}$

소엽성 모세혈관종이 발생하는 기전에 대해서는 명확히 밝 혀져 있지 않으나, 임신 및 경구 피임약과 연관성이 있어 호르 몬의 변화가 영향을 미치는 것으로 추정되며, ${ }^{10)}$ 몇몇 보고에 따르면 국소 외상 이후에 종양이 발생하였다고 하였다. ${ }^{11)}$ 크 기가 큰 경우 수술 중 다량의 출혈을 동반하여 내시경적 접 근법으로는 적출이 어려울 수 있으므로 술전 혈관 색전술을 시행하여야 할 수 있다. ${ }^{9}$ 또한 수술적 절제 후 재발율이 약 $15 \sim 42 \%$ 정도로 보고된 바 있어 추적 관찰에 주의해야 한 다. ${ }^{3,12)}$ 소엽성 모세혈관종의 재발에 미치는 요인에 대한 이전 의 한 연구에서, 고령의 나이이거나 수술적 완전 절제가 아닌 부분 절제가 시행된 경우에 재발률이 더 높은 것으로 보고 되었으며, 성별이나 유경성(pedunculated) 종물 혹은 융기형 (polypoid) 종물인지에 따른 형태에 의한 재발률 차이는 없 다고 하였다. ${ }^{12}$ 입술이나 피부 등 타 부위에서 발생한 경우 재발률이 약 $3 \%$ 정도로 보고된 것과 비교하였을 때, 비강 내 소엽성 모세혈관종의 재발률이 상대적으로 높은 이유는 수 술 시야가 좁고 비강의 혈류가 풍부하기 때문일 것이라고 해 당 논문에서 저자들은 기술하였다. ${ }^{12}$

저자들이 알아본 바에 따르면, 본 증례는 비부비강 내에서 의 발생이 비교적 드문 질환인 다형성 선종 및 소엽성 모세혈 관종이 편측 비중격 점막에서 동시에 발생한 최초 보고이다. 두 질환을 치료할 경우에는 두 질환의 재발 가능성 및 다형 성 선종의 악성화 가능성을 고려해서 종괴의 위치 및 크기에 따라 적절한 수술적 절제 방법을 선택해야 하며, 수술적 치료 이후 지속적인 추적 관찰이 필요할 것으로 사료된다.

\section{Author Contribution}

Conceptualization: Ji Ho Choi. Data curation: Yun Ji Lee, Shin Young Kim. Formal analysis: Ji Ho Choi, Jiyoon Kim. Investigation: Yun Ji Lee, Shin Young Kim. Methodology: Ji Ho Choi, Jiyoon Kim. Project administration: Ji Ho Choi. Supervision: Ji Ho Choi, Jiyoon Kim. Visualization: Yun Ji Lee, Jiyoon Kim. Writing - original draft: Yun Ji Lee. Writing — review \& editing: Ji Ho Choi, Yun Ji Lee.

\section{ORCIDs}

Ji Ho Choi

Yun Ji Lee

https://orcid.org/0000-0002-5194-930X

https://orcid.org/0000-0002-6238-1801

\section{REFERENCES}

1) Rha MS, Jeong S, Cho HJ, Yoon JH, Kim CH. Sinonasal pleomorphic adenoma: A single institution case series combined with a comprehensive review of literatures. Auris Nasus Larynx 2019; 46(2):223-9.

2) Gnepp DR. Malignant mixed tumors of the salivary glands: A review. Pathol Annu 1993;28 Pt 1:279-328.

3) Mills SE, Cooper PH, Fechner RE. Lobular capillary hemangioma: The underlying lesion of pyogenic granuloma. A study of 73 cases from the oral and nasal mucous membranes. Am J Surg Pathol 1980;4(5):470-9.

4) Vento SI, Numminen J, Kinnunen I, Rautiainen M, Tarkkanen J, Hagström J, et al. Pleomorphic adenoma in the nasal cavity: A clinicopathological study of ten cases in Finland. Eur Arch Otorhinolaryngol 2016;273(11):3741-5.

5) Li W, Lu H, Zhang H, Lai Y, Zhang J, Ni Y, et al. Sinonasal/ nasopharyngeal pleomorphic adenoma and carcinoma ex pleomorphic adenoma: A report of 17 surgical cases combined with a literature review. Cancer Manag Res 2019;11:5545-55.

6) Seok J, Hyun SJ, Jeong WJ, Ahn SH, Kim H, Jung YH. The difference in the clinical features between carcinoma ex pleomorphic adenoma and pleomorphic adenoma. Ear Nose Throat J 2019;98(8): 504-9.

7) Toluie S, Thompson LD. Sinonasal tract adenoid cystic carcinoma ex-pleomorphic adenoma: A clinicopathologic and immunophenotypic study of 9 cases combined with a comprehensive review of the literature. Head Neck Pathol 2012;6(4):409-21.

8) Witt RL. The significance of the margin in parotid surgery for pleomorphic adenoma. Laryngoscope 2002;112(12):2141-54.

9) Tamaki A, Babajanian E, D’Anza B, Rodriguez K. Lobular capillary hemangiomas: Case report and review of literature of vascular lesions of the nasal cavity. Am J Otolaryngol 2017;38(3): 363-6.

10) Delbrouck C, Chamiec M, Hassid S, Ghanooni R. Lobular capillary haemangioma of the nasal cavity during pregnancy. J Laryngol Otol 2011;125(9):973-7.

11) Gregorio LL, Wu CL, Busaba NY. Lobular capillary hemangioma formation: An unusual complication of submucous resection with power instrumentation of the inferior turbinate. Laryngoscope 2015;125(12):2653-5.

12) Smith SC, Patel RM, Lucas DR, McHugh JB. Sinonasal lobular capillary hemangioma: A clinicopathologic study of 34 cases characterizing potential for local recurrence. Head Neck Pathol 2013;7(2):129-34.

\section{Acknowledgments}

None. 